Innowacje w Pielęgniarstwie i Naukach o Zdrowiu

1(1)/2016

ISSN: 2451-1846

DOI: http://dx.doi.org/10.21784/IwP.2016.006

Anna Antczak ${ }^{1}$, Robert Ślusarz ${ }^{1}$

${ }^{1}$ Department of Neurological and Neurosurgical Nursing, at Ludwik Rydygier Collegium

Medicum in Bydgoszcz, Nicolaus Copernicus University in Toruń

\title{
Rola edukacyjna pielęgniarki \\ w opiece nad pacjentem $z$ chorobą \\ Alzheimera i jego rodziną
}

The educational role of nurses

in the care of patients with Alzheimer's

disease and the family

\section{Streszczenie:}

Choroba Alzheimera ma charakter neurodegradacyjny i należy do chorób postępujących. Zaliczana jest jako najczęstsza przyczyna choroby otępiennej wieku podeszłego. Częstość występowania gwałtownie wzrasta w grupie ludzi powyżej 65 roku życia. Charakterystycznymi objawami są zaburzenia funkcji poznawczych oraz funkcjonalnych. Wraz z postępem choroby, a tym samym nasileniem objawów zwiększa się zakres działań opiekuńczo-pielęgnacyjnych wobec pacjenta. Rola pielęgniarki uwarunkowana jest stanem funkcjonalnym pacjenta oraz zapotrzebowaniem na profesjonalną opiekę. Obszar działań odzwierciedla deficyty w wykonywaniu czynności 
samoobsługowych oraz brak wiedzy opiekunów. Pielęgniarka powinna określić problemy pacjenta i jego rodziny, postawić cele do wykonania, wdrożyć odpowiednie środki realizacji oraz ocenić działania.

Edukacja pacjenta to proces kolejno następujących, powiązanych logicznie i przyczynowo czynności, które są podejmowane w celu wywołania zmian w zachowaniu pacjenta. $\mathrm{W}$ związku z progresją choroby i w konsekwencji całkowitej niesamodzielności, wymaga od pielęgniarki odpowiedniej postawy adekwatnej do wykonywanej pracy oraz wyróżniającej się dużą moralnością. Rola edukacyjna w przypadku pacjentów z AD oraz ich rodzin odgrywa znaczącą rolę w procesie leczenia. Zapewnia poczucie bezpieczeństwa oraz wsparcia psychicznego. Pacjent na każdym etapie choroby ma zapewnianą odpowiednią jakość życia. Poza tym przygotowuje rodzinę do opieki nad pacjentem w warunkach domowych oraz wskazuję różne drogi rozwiązania problemów.

\section{Abstract:}

Alzheimer's disease is of neurodegrading nature and belongs to progressive diseases. It is classified as the most common cause of dementia disease of old age. The incidence is rapidly increasing in the group of patients over 65 years of age. The characteristic symptoms include cognitive and functional disorders. As the disease progresses, and thus the severity of symptoms increases the scope of activities related to patient care grows. The role of nurses is conditioned by the patient's functional status and demand for professional care. The area of activities reflects deficits in carrying out self-service and the lack of caregivers' knowledge. The nurse should identify patients' problems and as well as those of their families, define the goals to be reached, implement appropriate measures and evaluate the actions.

Patient's education is a process of successive, logically and causally related steps that are being taken in order to induce changes in the behavior of the patient. In connection with the progression of the disease and, consequently, total reliance, it requires from nurses appropriate attitude adequate to the work performed and characterised by outstanding high morality. The educational role in the case of patients with $\mathrm{AD}$ and their families plays a significant role in the process of treatment. It provides a sense of security and psychological support. The patient at every stage of the disease is guaranteed to have adequate quality of life. Also, it prepares the family to the care of the patient at home and defines various ways to solve problems. 
Słowa kluczowe: rola edukacyjna, pielęgniarka, pacjent, choroba Alzheimera

Keywords: the role of education, nurse, patient, Alzheimer's disease

\section{Introduction}

Alzheimer's disease (Alzheimer 's disease , AD) is a neurodegenerative disease of a complex etiology and pathogenesis. It belongs to one of the most common diseases of substrates dementia in the age group over 65 years of age. In addition, according to research it accounts for more than half of all cases of dementia in this age group. Based on statistics, it can be specified that in Poland on over 400,000 people suffer from Alzheimer's disease. In contrast, in the world this problem affects $10 \%$ of the population. It is a global problem and is defined as a disease of civilization [1,2]. With age, the percentage of patients increases, and thus the number of those requiring full or partial protection. AD is one of the progressive and chronic diseases, the therapy applied aims at slowing down the progress of the symptoms occurring.

The criterion conditioning the identification of Alzheimer's disease, as it has already been mentioned, is the age of the patient. It is considered to be the most important risk factor, and it is defined that with age the risk of diagnosis significantly increases. The determinant defined in studies is the age of 65 . Above that age the risk of developing dementia symptoms doubles every five years. Some studies indicate that more than $50 \%$ of population aged over 85 years suffer from AD. Also, the factors referred to in literature as predisposing factors are those resulting from genetics, gender and improper lifestyle. Hereditary factor indicates an increased risk for a person diagnosed with Alzheimer's disease. Geneticists are still working on the updating the data on genes predisposing to the emergence of the disease. Another factor considered is gender, there has been discovered a relationship which specifies that AD is more often diagnosed in women. Research show the impact of loss of estrogen due to menopause and 
the fact that women live longer. As far as improper lifestyle is concerned, researchers have identified the impact of smoking, and overweight as both a predisposing andmodifiable factor. Some results indicate an increased risk of disease in the case of smokers by $50 \%$. In contrast, overweight and obesity affects the development of other diseases such as hypertension, diabetes and cardiovascular disease, which can also contribute to the diagnosis of dementia. All these risk factors are confirmed by scientific research [3].

\section{Review}

\section{Problems of patients diagnosed with Alzheimer's disease}

The characteristic symptoms are cognitive and functional disorders. Also, changes occur in emotional and social reactions, in behavior, and motivation. The first characteristic signs are usually ignored. In the course of the disease it comes to disturbances in thinking, concentration and evaluation. There are difficulties with orientation regarding time, place and oneself. In addition, there occur difficulties regarding the language, reading comprehension, and counting. In the interviews the families of patients refer to minor memory disorders, involving difficulties in naming the object or the inability to perform simple tasks that did not use to be a problem. Gradually it develops to very serious stages often threatening patient's health or life. Memory disorders lead to leaving the house in search forflatmates or uncontrolled turning on electrical appliances. Care of the patient with AD at this stage of the disease requires 24-hour control. In addition, in the first phase of the disease there might occur depression, connected with difficulties in understanding one's own illness. This results from the deterioration of cognitive abilities, with which patients are knowledgeable about the changes undergoing in their bodies. Apart from that, with the development of the disease there appears aggressive behavior, both to the patient himself as well asto the patient's family. Changes in behavior also result from difficulties to understand 
the environment. The reality of the patient becomes very complicated, and complex activities trigger anxiety and fear. The family often enhances these behaviors through restrictions caused by deficiencies in knowledge $[4,5,6]$.

In addition to psychiatric disorders, typical for this disease, particular attention shouldbe paid to the nursing problems related to the performanceof basic life activities. As the disease progresses, and thus the severity of symptoms increases, the scope of activities related to patient care grows. Evolutionary nature of this disease results in dependency on the assistance of others, as well as in overall patient care. Patient's difficulties consist in the maintenance of appropriate body hygiene and in satisfying physiological needs.

Cognitive impairment results in limitations in the performanceof basic activities. The patient does not remember the scope of activities to be carried out with basic activities which include having meals, hygiene, getting dressed or washing. Those restrictions do not result from movement dysfunctions, but they can affect them directly. The patient is not able to properly nourish and hydrate the body by himself. He lacks regularity in having meals asthey are simply forgotten. Assistance of caretakers ought to be adjusted to the current condition of the patient.

All those aforementioned issues directly affect the life and functioning of the whole family. The patient, before the diagnosis of the disease, had functioned properly in a family environment. In their interviews the family often do not specify the first symptoms appearing, treating them as conditions caused by stress or fatigue $[7,8]$.

\section{The educational role of the nurse}

Health education is a process in which one learns to take care of their own health and the health of other people in the society. It consists of several stages, following and sometimes overlapping each other. Its beginning is at the stage of becoming aware of health issues in order to make decisions and take actions aimed at changing health 
behavior. It is distinguished by exposing the relationship between human health and the physical and social environment in which one functions [9].

Health education aims at developing health-promoting education. It is a long-term and multi-stage process. Actions taken in this direction are focused on a positive approach to health promoting a healthy lifestyle. It totally rejects actions that could endanger health or human life. Modifiable factors, affected directly by the man,are rejected,by arguing ,inter alia, their influence on the development of civilization diseases.

Education of patients and their families is a very important element in the process of treatment. Awareness of the nature of the disease as well as of the therapy implemented makes it possible to achieve considerably better effects of treatment $[10,11,12]$.

The role of nurses is conditioned by the patient's functional status and demand for professional care. The area of activities reflects deficits in carrying out self-service and the lack of caregivers' knowledge. The nurse should identify patients' problems and as well as those of their families, define the goals to be reached, implement appropriate measures and evaluate the actions. The leading essence of care is primarily to preserve the longest possible independence. The specificity of work in the neurology ward determines the approach to the patient both with the logical contact preserved, as well as with cognitive disorders in the case of whichthe contact is much more difficult $[13,14]$.

An example of such dementia are diseases that significantly restrict proper communication in the patient-nurse relationship. Nursing care in the case of patients with problems in verbal communication must be individually adjusted according to the needs of the patient and depend on his current health condition. In view of the progress of the disease, rapid changes in the behavior of such patients are observed [15]. 
Nursing covers a full range of activities in the field of patients with dementia. Depending on the severity of the symptoms assistance is extended and further procedures are introduced. The patient requires assistance in all spheres of life. In physical terms, appropriate conditions ought to be provided for the purpose of appropriate functioning. The nurse should assist in the field of self-care, depending on the degree of patient's dysfunction. In this case particular attention should be focused on patient's family, because the disease also refers directly to the caregivers of such a person. Both the patient as well as his family should receive psychological support from the medical staff.

The task the nurse has to manage in connection with dementia is to provide a sense of security for the patient in the case of difficulty with understanding many events which can generate anxiety, where asthe patient's family ought to be sure that they will not be left on their ownin the care of the patient. The role of nurses, should there appear problems in communication in the care of the patient, is to answer questions with patience, even if they have already been answered more than once. It is also important to repeat information such as that regarding operations scheduled, timetable, introducing oneself to the patient, in order to reduce the sense of insecurity [16, $17,18]$.

As regards the educational role, the nurse should be patient, understanding and reserved in expressing opinion. The nurse cannot assess patients and their families, because each person in a difficult situation might behave in a different way. She must have the ability to listen, and notice details that may affect the assessment of the patient [19].

Working with neurological patients should be based on defining priorities related to care in relation to a particular patient or a group of patients with a particular disease unit. On the basis of the patient's neurological problem determination and based on the interpretation of occurring symptoms of the disease, on the results of diagnostic 
tests and analysis of the collected data concerning the patient's condition, to indicate the appropriate measures to be implement individually, and at the same time in a holistic approach. Nursing should satisfy the physical, psychological and social realm of the patient. A properly adjuste dmodel of care can implement appropriate and targeted care $[20,21]$.

Taking care of someone with Alzheimer's disease and their nurturing is extremely complex. It requires the full commitment and the necessary and technical knowledge on the part of all members of the therapeutic team dealing with the patient. Support from professional therapeutic team is extremely important. Nursing care includes not only the performance of professional diagnostic procedures, but also assistance in daily activities, accompanying, supporting and educating the patient as well as their families. Raising the standards of nursing care of the elderly is of fundamental importance for the quality of livesof patients, caregivers and health care staff themselves.

\section{Conclusions}

To sum up, care of a patient diagnosed with Alzheimer's disease requires knowledge and skills, but above all an appropriate professional attitude. Depending on at what stage of the disease the patient is, individualized care should be adapted to their needs and dysfunctions and at the same time the patient should be perceivedholistically. A holistic approach means appropriate care in all spheres of life. The patient despite the accompanying symptoms and problems is to be provided with adequate quality of life. The patient's family also requires support and needs to be provided with a sense of security. In a situation of accumulated problems related to care, due care and concern should be provided and possible ways to solve problematic situations defined.

The nurse fulfilling the educational function to the patient with AD must have a broad knowledge in areas closely related to the disease unit and have the skills to carry out due care. The nurse is 
obliged to continuous training in order to improve competence. The nurse should, through their actions demonstrate professionalism. Apart from the knowledge and skills they should also reveal high social competence. In contact with a patient the nurse must have patience, understanding, and forbearance. At later stages of the disease verbal contact with the patient is very difficult. The staff should be able to read the signals sent by the patient in non-verbal patient contact $[22,23,24]$.

The educational role of nurses should be aimed at gaining the confidence of both the patient as well as his family. That should result in the assistance given to the patient and not in the performance activities for and instead of the patient. In the case of Alzheimer's disease it is crucial to maintain independence as long as possible, in order to improve the quality of life $[25,26]$.

\section{Bibliografia/Bibliography:}

1. Pabiś M., Ślusarska B., Jarosz M.J., Zarzycka D., Dobrowolska B., Brzozowska A. Kompetencje pielęgniarek w zakresie edukacji zdrowotnej w polskim systemie opieki medycznej. Pielęgniarstwo XXI wieku. 2010;Nr 3-4:(32-33).

2. Glińska J., Lewandowska M. Autonomiczność zawodu pielęgniarskiego $\mathrm{w}$ świadomości pielęgniarek z uwzględnieniem pełnionych funkcji zawodowych. Problemy Pielęgniarstwa. 2007; tom 15, zeszyt nr 4.

3. Franek G.A., Łukasz-Paluch K., Cholewka B. Koncepcja roli zawodowej pielęgniarki w literaturze przedmiotu. Problemy Pielęgniarstwa, 2012;20(2):252-259.

4. Rutkowska A. Problem psychologicznej pomocy chorym neurologicznie i ich rodzinom. Folia Psychologica, Warszawa 1997. 
5. Schwarz G. Choroba Alzheimera. Objawy, leczenie, opieka, pomoc. Wydawnictwo Lekarskie PZWL, Warszawa 2002.

6. Grochowska D. Opieka pielęgniarska nad pacjentem z chorobą Alzheimera. Magazyn Pielęgniarki i Położnej. 2001;1:37-38.

7. Kłoszewska I. Choroba Alzheimera. Przew Lek. 2001;4(11): 78-82.

8. Pfeffer A. Choroba Alzheimera - obraz kliniczny, rozpoznawanie, możliwości terapeutyczne zaburzeń poznawczych. Przew Lek. 2004;5: 70-78. 